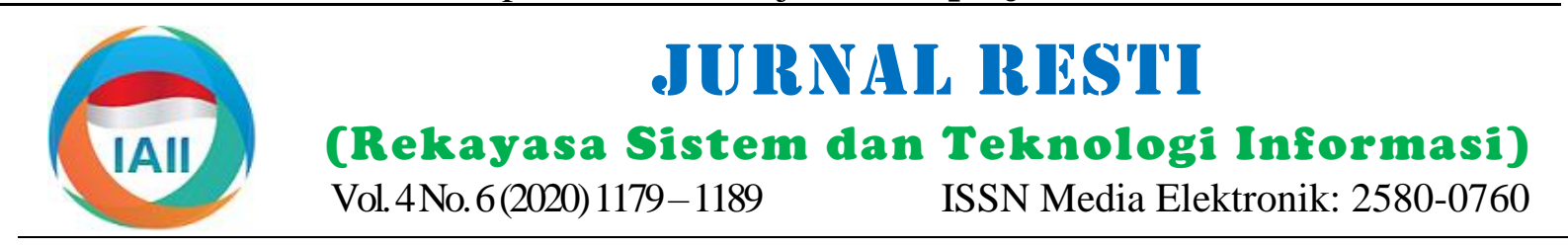

\title{
Analisis Data Sistem Informasi Geografis Rumah Tidak Layak Huni (RTLH) Menggunakan Metode Fuzzy Logic
}

\author{
Khairil Hamdi \\ Sistem Informasi,STMIK Jayanusa Padang, \\ khairilhamdi@jayanusa.ac.id
}

\begin{abstract}
Houses and other types of housing are things that cannot be separated from the needs of human life. Proper housing is the basic need of all people who will strengthen the family, as the main pillar of the nation's strength, at the same time acting as a bastion against various health risks. The properness of a house for family housing becomes the basis for the growth and development of a better family life. Roofs, floors, and walls (aladin) are indicator data of whether a house is proper or not at the time of the survey. This study describes how to process data using fuzzy logic methods with the linguistic attributes of roof conditions, floor conditions and wall conditions using the Matlab tool. The method used is the Fuzzy Inference System using the max-min method which has a membership degree of min 0 and max 1, followed by implication and defuzzication functions. To determine which housing are categorized as severely damaged, moderate and lightly damaged as the output of the feasibility variable, the purpose of using this method is the known results that are not only feasible or not feasible, but the feasibility value is known in the range of $0-100 \%$. So that local governments will find it easier to sort work priorities in the short, medium and long term.
\end{abstract}

Keywords: Fuzzy theory, Mamdani, GPS, WebGIS

\begin{abstract}
Abstrak
Rumah dan jenis hunian lainnya merupakan hal yang tidak bisa dipisahkan dari kebutuhan hidup manusia. Hunian yang layak merupakan kebutuhan dasar semua orang yang akan memperkuat keluarga, sebagai pilar utama kekuatan bangsa, sekaligus berperan sebagai benteng pertahanan melawan berbagai risiko kesehatan. Kelayakan rumah untuk hunian keluarga menjadi dasar tumbuh dan berkembangnya kehidupan keluarga yang lebih baik. Atap, lantai, dan dinding (aladin) merupakan data indikator dari layak atau tidak layaknya rumah pada saat survei dilakukan. Penelitian ini menjelaskan tentang bagaimana cara proses data menggunakan metode logika fuzzy dengan atribut linguistic kondisi atap, kondisi lantai dan kondisi dinding menggunakan tool matlab. Metode yang digunakan adalah Fuzzy Inference System menggunakan metode max-min yang memiliki derajat keanggotaan min 0 dan max 1, dilanjutkan dengan fungsi implikasi dan defuzyfikasi. Data yang terkumpul dari survey kemudian diberi bobot angka, nilai yang sudah didapatkan akan menjadi input kedalam Fuzzy Inference System sehingga diperoleh hasil akhir nilai kelayakan dengan rentang $0-100 \%$ sebagai output variable kelayakan, sehingga bisa disimpulkan hunian mana yang dikategorikan sebagai rusak parah, sedang, dan ringan, tujuan menggunakan metode ini hasil yang diketahui tidak hanya layak atau tidak layak melainkan diketahuinya sehingga pemerintah daerah akan lebih mudah mengurutkan prioritas pekerjaan dalam jangka waktu pendek, sedang dan panjang.
\end{abstract}

Kata kunci: Teori Fuzzy, Mamdani, GPS, WebGIS

\section{Pendahuluan}

Seiring dengan penyelenggaraan era otonomi daerah, sektor pembangunan perumahan dan kawasan permukiman tersebut juga telah diatur lebih lanjut dalam Peraturan Pemerintah [1], rumah layak huni adalah rumah yang memenuhi persyaratan keselamatan bangunan dan kecukupan minimum luas bangunan serta kesehatan penghuninya [2], pembagian urusan pemerintahan antara pemerintah, pemerintahan daerah propinsi, dan pemerintahan daerah kota/ kabupaten lampiran yang menyatakan perlunya pemerintah kota/kabupaten menyusun data tentang perumahan dan kawawan permukiman.

Rumah juga memiliki peran strategis sebagai pusat pendidikan keluarga, budaya dan perwujudan jati diri

Diterima Redaksi : 22-11-2020 | Selesai Revisi : 13-12-2020 | Diterbitkan Online : 20-12-2020 
dalam upaya peningkatan kualitas bagi generasi dinding dan/atau atap terbuat dari bahan yang mudah mendatang[3], saat ini rumah layak huni adalah rusak/lapuk, lantai terbuat dari tanah, papan, kebutuhan dasar semua orang yang akan memperkuat bambu/semen, atau keramik dalam kondisi rusak, tidak keluarga, sebagai pilar utama kekuatan bangsa, memiliki tempat mandi, cuci, dan kakus; dan/atau luas sekaligus berperan sebagai benteng pertahanan melawan lantai kurang dari 7,2 m2/orang (tujuh koma dua berbagai risiko kesehatan termasuk pandemi covid 19 meter persegi perorang) [5] pengumpulan data rumah [4]. dilakukan oleh tenaga surveyor dari beberapa instansi Pemerintah seperti BPS atau Dinas Perumahan dan

Kriteria rumah tidak layak huni yang dapat diperbaiki meliputi: dinding dan/atau atap dalam kondisi rusak yang dapat membahayakan keselamatan penghuni,

Kawasan Permukiman (Perkim) dengan perangkat mobile [6].

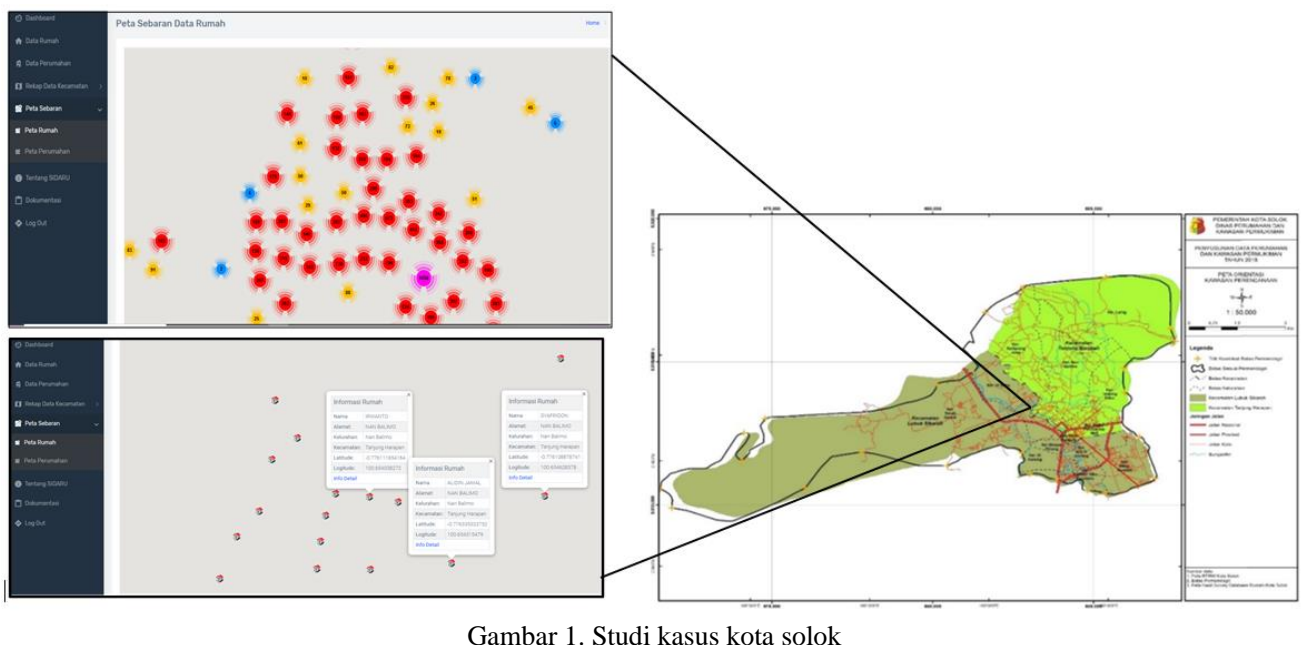

Secara umum, proses survei data kelayakan mengacu rumah, dengan kriteria jumlah angkatan umur menikah pada jenis material, kondisi pada variable atap, dinding dan jumlah rumah yang tidak layak huni dalam suatu dan lantai bangunan (aladin) [7], pembangunan wilayah kecamatan/desa. dari data tersebut dibuatkan perumahan dan kawasan permukiman merupakan salah daftar inventarisasi rumah tidak layak huni dilihat dari 3 satu urusan pemerintahan konkuren yang menjadi (tiga) komponen tingkat kerusakan yaitu: atap, lantai kewenangan daerah[8] dalam mempersiapkan program, dan dinding [9]. perlu terlebih dahulu disusun jumlah kebutuhan akan

Tabel 1. Dasar hukum indikator atap, lantai dinding

\begin{tabular}{|c|c|c|c|c|c|c|}
\hline \multirow{2}{*}{$\begin{array}{l}\text { Peraturan dan } \\
\text { Instansi }\end{array}$} & \multirow[b]{2}{*}{ Luas minimum } & \multicolumn{4}{|c|}{ Keselamatan Bangunan } & \multirow{2}{*}{$\begin{array}{l}\text { Kesehatan } \\
\text { Penghuni }\end{array}$} \\
\hline & & $\begin{array}{c}\text { Struktur } \\
\text { Bangunan }\end{array}$ & Material Dinding & $\begin{array}{c}\text { Material } \\
\text { Atap }\end{array}$ & $\begin{array}{c}\text { Material } \\
\text { Lantai }\end{array}$ & \\
\hline $\begin{array}{l}\text { Permenpera No. } \\
22 / \text { Permen/M/2008 }\end{array}$ & $\begin{array}{l}7,2-12 \\
\mathrm{~m} 2 / \text { orang }\end{array}$ & $\begin{array}{l}\text { Pondasi, kolom- } \\
\text { balok dan } \\
\text { rangka atap }\end{array}$ & & & & $\begin{array}{l}\text { Pencahayaan, } \\
\text { penghawaan } \\
\text { dan Sanitasi }\end{array}$ \\
\hline $\begin{array}{l}\text { Permendagri No. } \\
21 / 2010\end{array}$ & $\begin{array}{l}\text { Kota }< \\
4 \mathrm{~m} 2 / \text { orang } \\
\text { Desa }<10 \\
\mathrm{~m} 2 / \text { orang }\end{array}$ & & $\begin{array}{l}\text { Anyaman bambu } \\
\text { yang belum } \\
\text { diproses }\end{array}$ & $\begin{array}{l}\text { Daun dan } \\
\text { lainnya }\end{array}$ & Tanah & $\begin{array}{l}\text { Tidak memiliki } \\
\text { MCK }\end{array}$ \\
\hline $\begin{array}{l}\text { Pergub Jabar No. } \\
46 / 2015\end{array}$ & & & $\begin{array}{l}\text { Bambu/sesk, } \\
\text { bilik, papan, kulit } \\
\text { kayu, tembok } \\
\text { rusak }\end{array}$ & $\begin{array}{l}\text { Rumbia, } \\
\text { seng, ilalang, } \\
\text { ijuk, genteng } \\
\text { rusak }\end{array}$ & $\begin{array}{l}\text { Tanah, papan, } \\
\text { bambu, semen } \\
\text { rusak }\end{array}$ & $\begin{array}{l}\text { Tidak punya } \\
\text { jamban, tidak } \\
\text { ada } \\
\text { ventilasi/jendela }\end{array}$ \\
\hline $\begin{array}{l}\text { Permensos No } \\
20 / 2017\end{array}$ & $<7.2 \mathrm{~m} 2$ /orang & $\begin{array}{l}\text { Kondisi } \\
\text { bangunan rusak } \\
\text { yang } \\
\text { membahayakan } \\
\text { penghuni }\end{array}$ & $\begin{array}{l}\text { Dinding dari } \\
\text { bahan mudah } \\
\text { rusak/lapuk }\end{array}$ & $\begin{array}{l}\text { Atap dari } \\
\text { bahan mudah } \\
\text { rusak/lapuk }\end{array}$ & $\begin{array}{l}\text { Tanah, papan, } \\
\text { bambu/semen } \\
\text { atau keramik } \\
\text { rusak }\end{array}$ & $\begin{array}{l}\text { Tidak memiliki } \\
\text { MCK }\end{array}$ \\
\hline $\begin{array}{l}\text { PermenPUPR No } \\
47 / \mathrm{PRT} / \mathrm{M} / 2015\end{array}$ & $<9 \mathrm{~m} 2$ orang & $\begin{array}{l}\text { Rusak berat, } \\
\text { rusak sedang }\end{array}$ & $\begin{array}{l}\text { Bilik } \\
\text { bambu/kayu/rotan }\end{array}$ & $\begin{array}{l}\text { Daun atau } \\
\text { genteng } \\
\text { plentong } \\
\text { rapuh }\end{array}$ & $\begin{array}{l}\text { Tanah atau } \\
\text { kayu }\end{array}$ & $\begin{array}{l}\text { Tidak } \\
\text { mempunyai } \\
\text { pencahayaan }\end{array}$ \\
\hline BPS & $<7.2 \mathrm{~m} 2$ /orang & & Bambu & Ijuk & Tanah & \\
\hline
\end{tabular}

Jurnal RESTI (Rekayasa Sistem dan Teknologi Informasi) Vol. 4 No. 6 (2020) 1179 - 1189 
Terkumpulnya data eksisting bangunan, perumahan dan pembobotan berupa nilai angka.

permukiman yang relevan dan signifikan dengan Tujuan dari penelitian ini adalah menentukan parameter penyusunan kebijakan, perencanaan, pemrograman, dalam kelayakan sebuah hunian, memberikan bobot nilai penganggaran, pemantauan dan evaluasi pelaksanaan angka terhadap parameter kondisi atap, kondisi lantai dan pembangunan perumahan dan permukiman [7].

WebGIS dapat menampilkan hasil data geografis informasi yang dihasilkan akan menjadi penunjang keputusan bagi organisasi/institusi[10], data hasil survei dapat ditampilkan melalui sistem informasi berbasis WebGIS [11]. Dalam kegiatan survei rumah, Dinas Perkim Kota Solok mengumpulkan beberapa informasi rumah dan pemiliknya dalam sebuah aplikasi menggunakan aplikasi Android bernama Form Survei Data Rumah (Forsuda) untuk memudahkan perekaman data secara digital agar lebih cepat dan efisien, data yang diperoleh.

Selanjutnya diolah sebagai penerapan logika fuzzy dengan metode mamdani efektif diterapkan dalam aplikasi software Matlab untuk menunjang keputusan [12][13], peneliti menggunakan logika fuzzy dengan bantuan software matlab untuk mensimulasikan cara berpikirnya manusia dalam menentukan hasil [14], sebagai penunjang keputusan proses dilakukan melalui metode mamdani ada empat tahap [15] yaitu pembentukan himpunan fuzzy(pembentukan variabel input maupun variabel output dibagi menjadi satu atau lebih himpunan fuzzy), aplikasi fungsi implikasi (fungsi implikasi ditentukan dari nilai yang berupa himpunan fuzzy yang digunakan sebagai implikasi yaitu nilai min atau nilai yang paling terendah), komposisi aturan (caracara yang digunakan untuk menentukan penilaian himpunan fuzzy), defuzzification(tahap terakhir untuk proses mengolah suatu himpunan fuzzy yang diperoleh dari komposisi aturan fuzzy untuk menghasilkan output berupa suatu bilangan pada domain himpunan fuzzy tersebut) [16].

Berdasarkan material atap berupa; genteng/asbes/seng* atau rumbia/daun kelapa/daun aren* dan kondisi atap; layak atau tidak layak menjadi variable kondisi atap, selanjutnya material lantai berupa; keramik, kayu, plester, bambu, tanah dan aspek keselamatan bangunan terdiri dari; kolom, pondasi, kontruksi menjadi variable kondisi lantai dan yang terakhir adalah bahan dinding berupa; bata/batako plester, bata/batako ekspose, kayu/papan atau asbes dengan kondisi tidak rusak, rusak sedang dan rusak berat akan menjadi variable kondisi dinding [9].

Data yang terkumpul selanjutnya dikelompokan sesuai kondisi atap yang terdiri dari bahan atap dan kondisi atap. Kondisi lantai terdiri dari bahan lantai, kondisi, pondasi, konstruksi dan kolom. Selanjutnya untuk kondisi dinding diperoleh dari bahan dinding, kondisi, ventilasi dan pencahayaan. Kemudian masing-masing variable diberi kondisi dinding, kemudian nilai yang didapatkan akan menjadi input yang nantinya akan diproses dalam FIS, sehingga diperoleh hasil akhir nilai kelayakan dengan rentang $0-100 \%$ sebagai output variable kelayakan, dari rentang terebut disimpulkan hunian mana yang dikategorikan sebagai rusak parah, sedang, dan ringan, tujuan menggunakan metode ini hasil yang diketahui tidak hanya layak atau tidak layak melainkan diketahuinya besaran nilai kelayakan sehingga pemerintah daerah akan lebih mudah mengurutkan prioritas pekerjaan dalam jangka waktu pendek, sedang dan panjang.

\section{Metode Penelitian}

Metode penelitian fokus pada sistem yang sudah berjalan sebagai objek penelitian. Bermula dari identifikasi masalah, mempelajari literature, pengumpulan data, meganalisa masalah, analisa kebutuhan fuzzy logic, analisa data (pengelompokan variable), merancancang system fuzzy, pengujian dengan metode mamdani, pengujian dengan software matlab, hasil. Tahapan tersebut diilustrasikan pada Gambar 1.

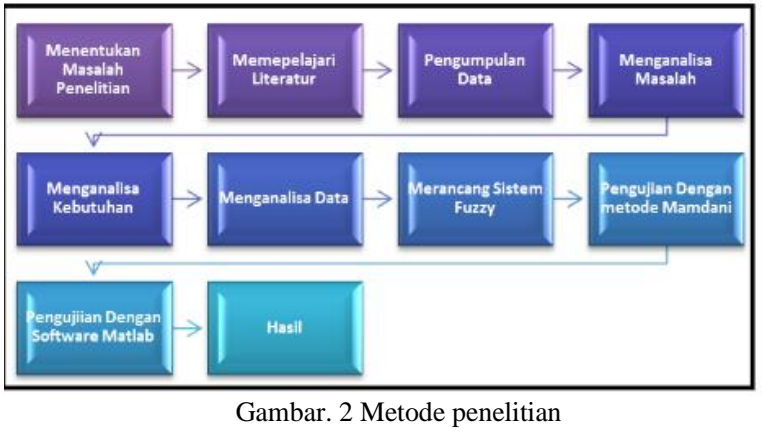

Objektivitas dan identifikasi masalah merupakan tahapan analisis awal pada aplikasi sistem yang sudah berjalan. Tahapan ini berfokus pada sistem pelacakan lokasi untuk kegiatan survei dan hasil data Rumah Tidak Layak Huni (RTLH) [17]. Sistem tersebut berjalan pada aplikasi Form Survei Data Rumah (Forsuda), yang selanjutnya akan dianalisis bentuk Fuzzy Inference System (FIS) menggunakan metode mamdani seperti gambar 8 :

\section{Fuzzyfikasi}

Tahap pertama dari prosedur metode fuzzy mamdani adalah pembentukan himpunan fuzzy atau dikenal pula dengan istilah fuzzifikasi, fuzzifikasi merupakan proses yang dilakukan dengan mengtransformasi input himpunan tegas (crisp) ke dalam himpunan fuzzy [18]. 
Hal ini dilakukan karena input yang digunakan awalnya adalah dalam bilangan tegas (real) dari suatu himpunan tegas (crisp).

Himpunan fuzzy ini didasarkan pada tingkatan linguistiknya yang dikelompokkan dalam suatu variabel fuzzy. Sebagai ilustrasi, untuk variabel fuzzy berat badan mempunyai himpunan fuzzy sebagai berikut: Kurang baik, cukup baik, baik, sangat baik.

$\mu$ Kurang Baik $[x]=\left\{\begin{array}{c}1 ; \quad x \leq a \\ (x-a) /(b-a) ; \quad a \leq x \leq b \\ 0 ; \quad \geq b\end{array}\right.$

$\mu$ Cukup Baik $[x]=\left\{\begin{array}{c}1 ; \quad x \leq a \\ (x-a) /(b-a) ; \quad a \leq x \leq b \\ 0 ; \quad \geq b\end{array}\right.$

$\mu$ Baik $[x]=\left\{\begin{array}{c}1 ; \quad x \leq a \\ (x-a) /(b-a) ; \quad a \leq x \leq b \\ 0 ; \quad \geq b\end{array}\right.$

$\mu$ Sangat Baik $[x]=\left\{\begin{array}{l}1 ; \quad x \leq a \\ (x-a) /(b-a) ; \quad a \leq x \leq b \\ 0 ; \quad \geq b\end{array}\right.$

\section{Kondisi atap}

Dilihat dari table dibawah ini variable atap dengan domain yang sudah ditentukan sebagai berikut :

Tabel. 2 Kondisi Atap

\begin{tabular}{cc}
\hline Himpunan & Domain \\
\hline Sangat Baik & {$\left[\begin{array}{ll}11 & 15\end{array}\right]$} \\
Baik & {$\left[\begin{array}{ll}9 & 13\end{array}\right]$} \\
Cukup Baik & {$\left[\begin{array}{ll}7 & 11\end{array}\right]$} \\
Kurang Baik & {$\left[\begin{array}{ll}0 & 8\end{array}\right]$} \\
\hline
\end{tabular}

Berdasarkan data yang ada pada tabel dapat dilihat kurva himpunan fuzzy kondisi atap sebagai berikut :

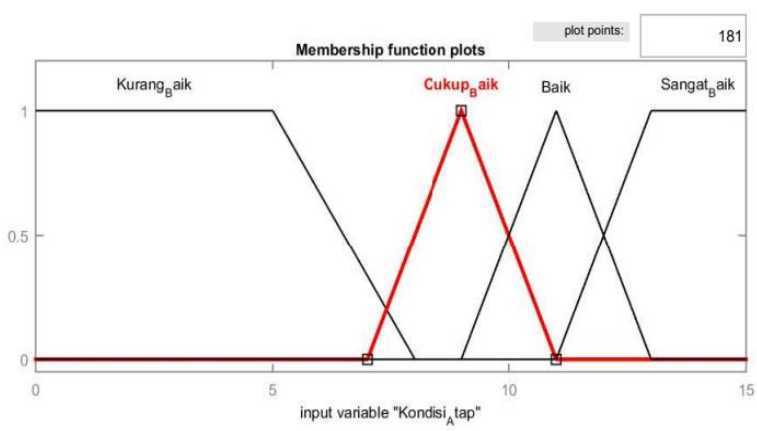

Gambar3. Kurva Variabel Kondisi Atap

\section{Kondisi lantai}

Dilihat dari table dibawah ini variable atap dengan domain yang sudah ditentukan sebagai berikut :
Tabel 3. Kondisi Lantai

\begin{tabular}{cc}
\hline Himpunan & Domain \\
\hline Sangat Baik & {$\left[\begin{array}{ll}20 & 30\end{array}\right]$} \\
Baik & {$\left[\begin{array}{lll}15 & 24\end{array}\right]$} \\
Cukup Baik & {$\left[\begin{array}{lll}10 & 20\end{array}\right]$} \\
Kurang Baik & {$\left[\begin{array}{ll}0 & 13\end{array}\right]$} \\
\hline
\end{tabular}

Berdasarkan data yang ada pada tabel dapat dilihat kurva himpunan fuzzy kondisi lantai sebagai berikut :

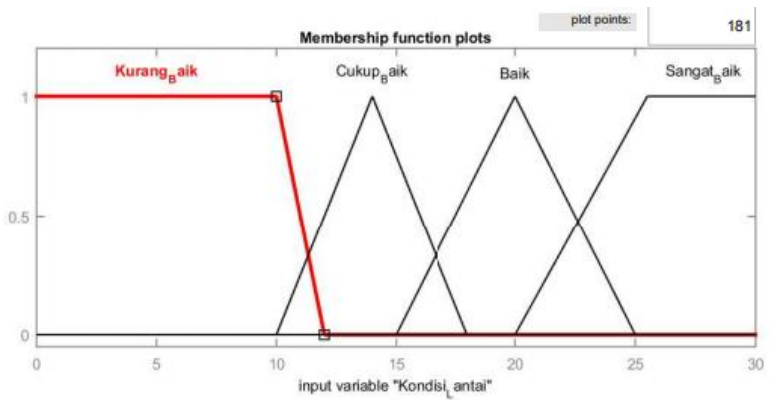

Gambar 4. Kurva Variabel Kondisi Lantai

\section{a. Kondisi dinding}

Dilihat dari table di bawah ini variable atap dengan domain yang sudah ditentukan sebagai berikut :

Tabel 4. Kondisi Dinding

\begin{tabular}{cc}
\hline Himpunan & Domain \\
\hline Sangat Baik & {$\left[\begin{array}{ll}2 & 30\end{array}\right]$} \\
Baik & {$\left[\begin{array}{lll}15 & 24\end{array}\right]$} \\
Cukup Baik & {$\left[\begin{array}{ll}8 & 17\end{array}\right]$} \\
Kurang Baik & {$\left[\begin{array}{ll}0 & 10\end{array}\right]$} \\
\hline
\end{tabular}

Berdasarkan data yang ada pada tabel dapat dilihat kurva himpunan fuzzy kondisi dinding sebagai berikut :

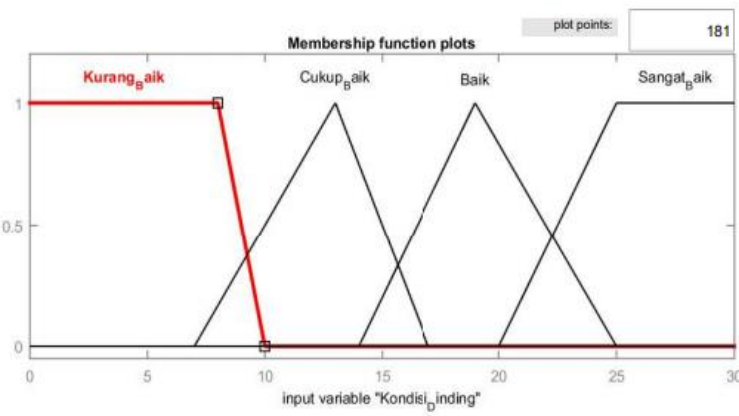

Gambar 5. Kurva Variabel Kondisi Dinding

Berdasarkan data yang ada pada tabel dapat dilihat bahwa untuk himpunan fuzzy sangat baik mempunyai domain 
[20 30]. Jadi apabila jumlah nilai yang diperoleh menggunakan penghubung fuzzy AND (interseksi) berdasarkan kategori penilaian berjumlah 27 maka setelah dilakukan tahap analisa data dan data sudah tergolong sangat baik, untuk himpunan fuzzy baik dikelompokkan maka pada tahap ini akan membahas mempunyai domain [15 24], apabila jumlah nilai yang tentang perancangan sistem dengan menentukan diperoleh berdasarkan kategori penilaian berjumlah 17 rancangan input, rule-rule, dan output yang akan maka tergolong ke dalam himpunan fuzzy baik, untuk diperlukan.

himpunan fuzzy cukup baik mempunyai domain [8 17], apabila jumlah nilai yang diperoleh berdasarkan kategori penilaian berjumlah 15 maka tergolong ke dalam himpunan fuzzy cukup baik, begitu juga untuk himpunan fuzzy kurang baik mempunyai domain [0 10], apabila jumlah nilai yang diperoleh berdasarkan kategori penilaian berjumlah 9 maka tergolong ke dalam himpunan fuzzy kurang baik Untuk kondisi atap sebagai berikut

\section{d. Variabel output}

Untuk variabel output dalam sistem ini adalah kelayakan, di mana variabel output kelayakan dibagi ke dalam dua bagian yaitu: RTLH dan RLH. Klasifikasinya dapat dilihat pada tabel di bawah ini:

Tabel 5. Variabel Kelayakan

\begin{tabular}{cc}
\hline Himpunan & Domain \\
\hline RTLH & {$\left[\begin{array}{ll}0 & 60\end{array}\right]$} \\
RLH & {$[50100]$}
\end{tabular}

Dari tabel di atas dapat dibuat fungsi keanggotaan untuk variabel output seperti di bahah ini:

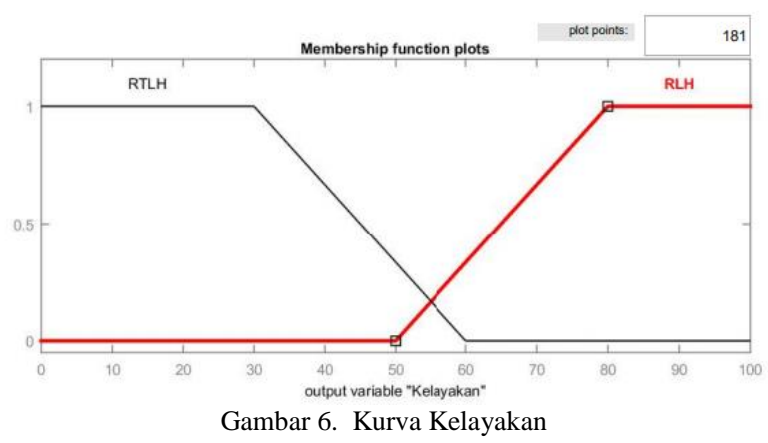

Tahap kedua dari prosedur metode fuzzy mamdani adalah penerapan fungsi implikasi. Fungsi implikasi merupakan struktur logika yang terdiri atas kumpulan premis dan satu konklusi. Fungsi implikasi berguna untuk mengetahui hubungan antara premispremis dan konklusinya. Bentuk dari fungsi implikasi ini adalah dengan pernyataan IF is THEN is, dengan dan adalah skalar, serta A dan adalah himpunan fuzzy.

Dalam istilah logika fuzzy, proposisi yang mengikuti IF disebut dengan antisenden, sedangkan proposisi yang mengikuti THEN disebut dengan konsekuen. Proposisi atau aturan fuzzy ini dapat diperluas dengan

$$
\begin{aligned}
& \text { A Rule Editor: FIS RTLH Aladin } \\
& \text { File Edit View Options }
\end{aligned}
$$

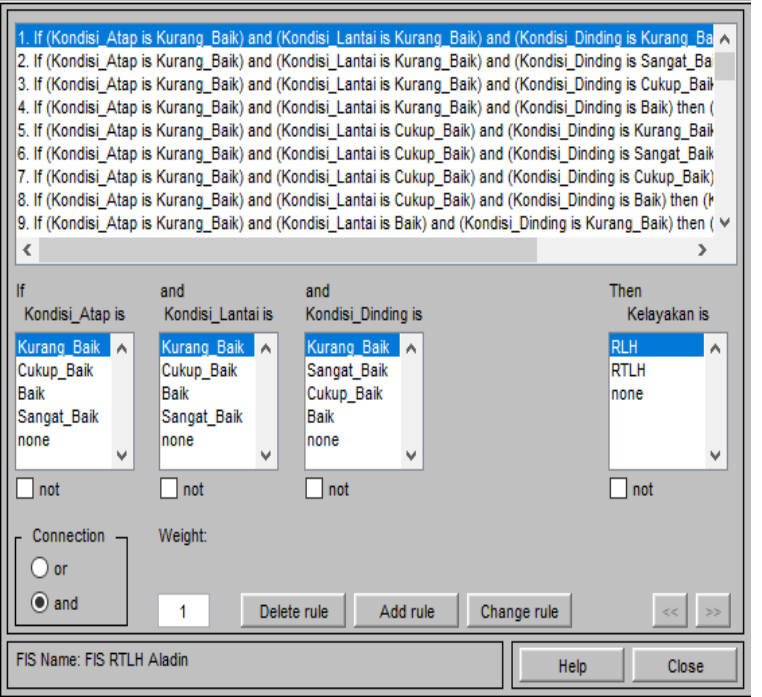

Gambar 7 Rule Editor

\section{Pembahasan dan hasil}

Mencantumkan bobot dari masing-masing parameter seperti tabel berikut ini :

Tabel 6. Bobot nilai parameter

\begin{tabular}{ll}
\hline \multicolumn{1}{c}{ Parameter } & \multicolumn{1}{c}{ Bobot } \\
\hline $\begin{array}{l}\text { Variabel kondisi atap } \\
\text { Material atap }(M a)\end{array}$ & $\Sigma=M a+K a$ \\
& $\begin{array}{l}\text { Genteng/asbes/seng atau } \\
\text { rumbia/daun kelapa/daun aren } \\
(6),(4),(2)\end{array}$
\end{tabular}

Kondis atap ( $\mathrm{Ka})$

Tidak Bocor, bocor sedang, bocor sedikt (7),(4),(2)

Variabel kondisi Lantai $\Sigma=M l+A K B p+A K B k l+A K B k$

Pondasi (AKBp)

Layak/tidak layak (6),(2)

Kolom (AKBkl)

Layak/tidak layak (6),(3)

Konstruksi ( $A K B k$ )

Material lantai $(M l)$

Layak/tidak layak (4),(2)

Keramik, kayu, plester, bambu, $\operatorname{tanah}(8),(8),(6),(4),(1)$

Variabel kondisi dinding

$\Sigma=V d+C d+M d+K d$

Ventilasi ( $V d)$

Ada/tidak (7),(4)

Pencahayaan $(C d)$

Ada/tidak (5),(3)

Bata/batako plester, bata/batako ekspose, kayu/papan atau asbes (7), (6),(5),(3) 
Tidak rusak, rusak sedang, rusak sedikt (6),(4),(2)

Hasil penilaian setiap variabel yang berbentuk bobot pada masing masing akan dijumlahkan sehingga nilai ini nantinya akan menjadi input pada sistem FIS, data yang digunakan sebanyak 19 dari 1 kelurahan di Kecamatan Tanjung Harapan Kota Solok, seperti yang terlihat pada tabel di bawah ini:

Tabel 7. Data input variable

\begin{tabular}{|c|c|c|c|c|c|c|c|c|c|c|c|c|c|c|c|c|}
\hline$\overline{N m}$ & $M a$ & $K a$ & $\Sigma$ & $M l$ & $A K B p$ & $A K B k l$ & $A K B k$ & $\Sigma$ & $\mathrm{Cd}$ & $\mathrm{Vd}$ & $\mathrm{Md}$ & $\mathrm{Kd}$ & $\Sigma$ & $\mu \mathrm{a}$ & $\alpha l$ & $\mu \mathrm{d}$ \\
\hline $\bar{A}$ & 6 & 7 & 13 & 8 & 6 & 6 & 4 & 24 & 5 & 7 & 2 & 5 & 20 & 13 & 24 & 21 \\
\hline B & 6 & 7 & 13 & 6 & 6 & 6 & 4 & 22 & 5 & 7 & 5 & 6 & 23 & 13 & 22 & 23 \\
\hline $\mathrm{C}$ & 6 & 7 & 13 & 8 & 6 & 6 & 4 & 24 & 5 & 7 & 5 & 6 & 23 & 13 & 24 & 23 \\
\hline D & 6 & 7 & 13 & 8 & 6 & 6 & 4 & 24 & 5 & 7 & 7 & 6 & 25 & 13 & 24 & 25 \\
\hline $\mathrm{E}$ & 6 & 7 & 13 & 6 & 6 & 6 & 4 & 22 & 5 & 7 & 7 & 6 & 25 & 13 & 22 & 25 \\
\hline $\mathrm{F}$ & 2 & 4 & 6 & 4 & 2 & 3 & 4 & 13 & 5 & 7 & 2 & 6 & 20 & 6 & 13 & 20 \\
\hline $\mathrm{G}$ & 4 & 4 & 8 & 1 & 6 & 6 & 4 & 17 & 5 & 7 & 5 & 4 & 21 & 8 & 17 & 21 \\
\hline $\mathrm{H}$ & 6 & 4 & 10 & 8 & 6 & 3 & 2 & 19 & 5 & 7 & 5 & 6 & 23 & 10 & 19 & 23 \\
\hline I & 6 & 7 & 13 & 8 & 6 & 6 & 4 & 24 & 5 & 7 & 7 & 6 & 25 & 13 & 24 & 25 \\
\hline $\mathbf{J}$ & 6 & 7 & 13 & 6 & 6 & 6 & 4 & 22 & 5 & 7 & 7 & 6 & 25 & 13 & 22 & 25 \\
\hline K & 6 & 7 & 13 & 6 & 6 & 6 & 4 & 22 & 5 & 7 & 7 & 6 & 25 & 13 & 22 & 25 \\
\hline $\mathrm{L}$ & 6 & 7 & 13 & 6 & 6 & 6 & 4 & 22 & 5 & 7 & 7 & 6 & 25 & 13 & 22 & 25 \\
\hline M & 6 & 7 & 13 & 6 & 6 & 6 & 4 & 22 & 5 & 7 & 7 & 6 & 25 & 13 & 22 & 25 \\
\hline $\mathrm{N}$ & 6 & 7 & 13 & 6 & 6 & 6 & 4 & 22 & 5 & 7 & 7 & 6 & 25 & 13 & 22 & 25 \\
\hline $\mathrm{O}$ & 6 & 7 & 13 & 6 & 6 & 6 & 4 & 22 & 5 & 7 & 7 & 6 & 25 & 13 & 22 & 25 \\
\hline $\mathrm{P}$ & 6 & 7 & 13 & 6 & 6 & 6 & 4 & 22 & 5 & 7 & 5 & 4 & 21 & 13 & 22 & 21 \\
\hline $\mathrm{Q}$ & 6 & 7 & 13 & 6 & 6 & 6 & 4 & 22 & 5 & 7 & 5 & 2 & 19 & 13 & 22 & 19 \\
\hline $\mathrm{R}$ & 6 & 7 & 13 & 6 & 6 & 6 & 4 & 22 & 5 & 7 & 5 & 2 & 19 & 13 & 22 & 19 \\
\hline $\mathrm{S}$ & 6 & 7 & 13 & 6 & 6 & 6 & 4 & 22 & 5 & 7 & 5 & 4 & 21 & 13 & 22 & 21 \\
\hline
\end{tabular}

Tabel 8. Penjelasan tabel atau singkatan

\begin{tabular}{cl}
\hline Singakatan & \multicolumn{1}{c}{ Keterangan } \\
\hline$N m$ & Nama kepala keluarga \\
$M a$ & Material atap \\
$K a$ & Kondisi atap \\
$\Sigma$ & Jumlah \\
$M l$ & Material lantai \\
$A K B p$ & Aspek keselamatan bangunan pondasi \\
$A K B k l$ & Aspek keselamatan bangunan kolom \\
$A K B k$ & Aspek keselamatan bangunan konstruksi
\end{tabular}



dibangun sebagai berikut :

\section{Software matlab}

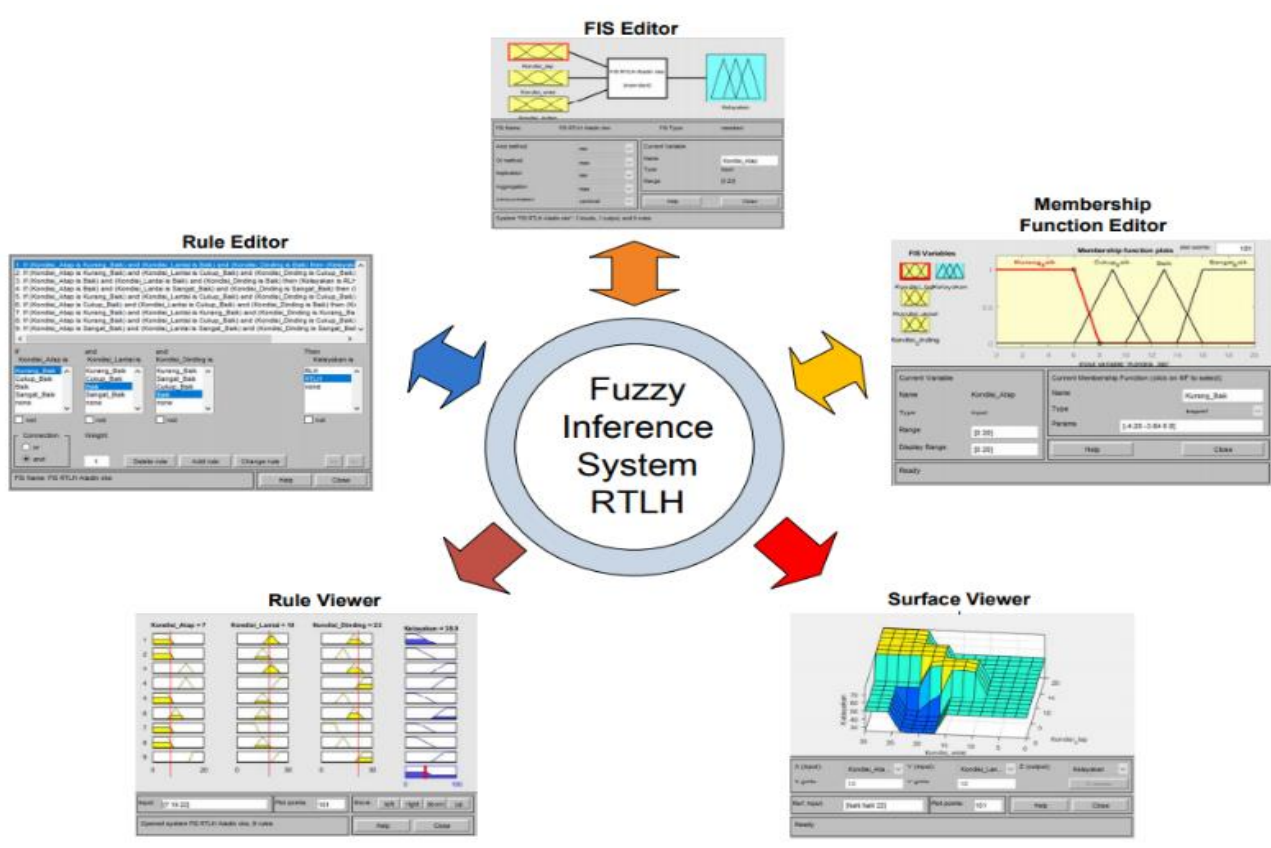

Gambar 8. Mamdani System

Didapatkan hasil dengan input 8, 17 dan 21 adalah 46.4 seperti gambar hasil berikut:

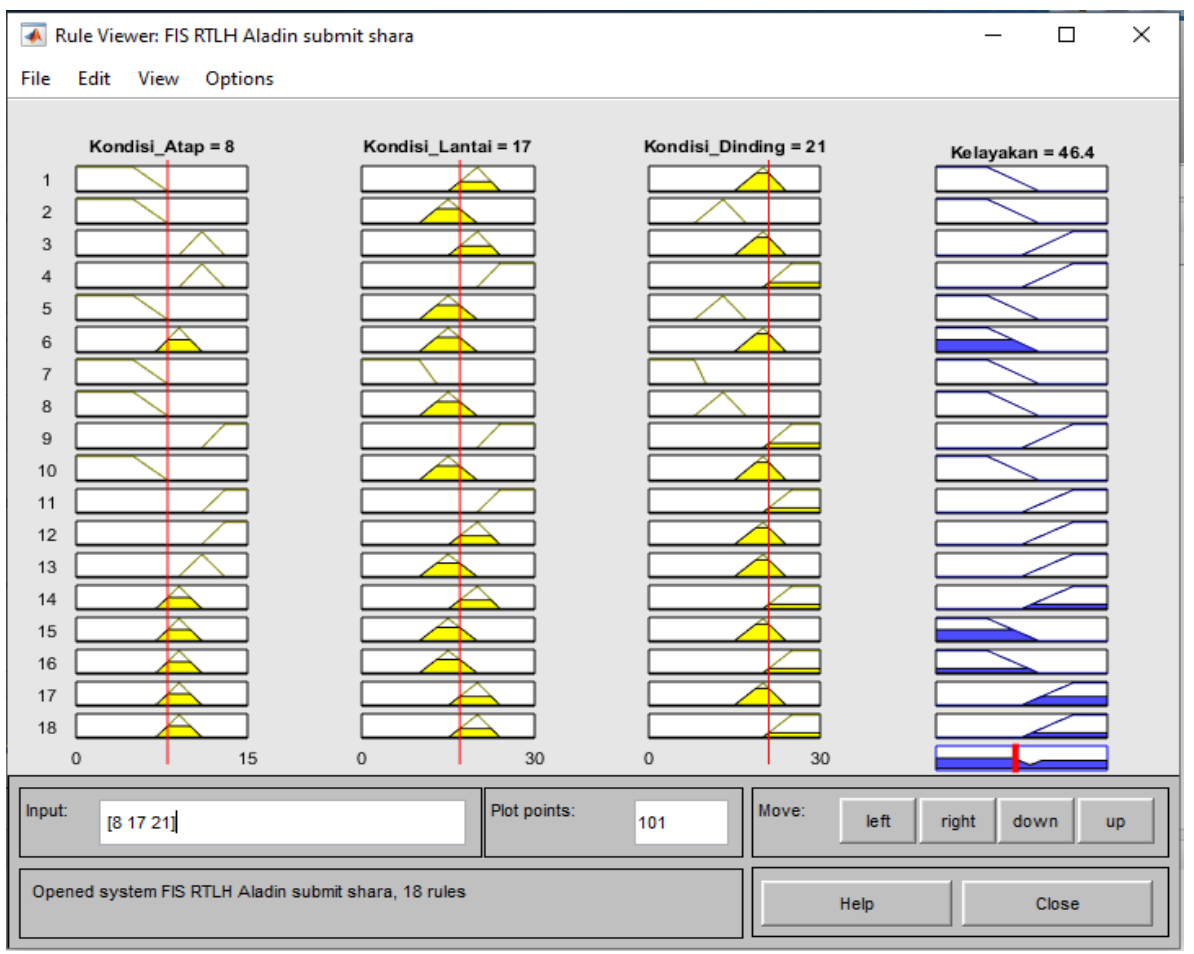

Gambar 9. Aplikasi view Rule (hasil penghitungan) pada Matlab 
Jika hasil yang diperoleh diurutkan berdasarkan persentasi terkecil adalah, seperti tabel di bawah ini:

Tabel 9. Hasil proses FIS

\begin{tabular}{|c|c|c|c|c|c|c|c|c|c|c|c|c|c|c|c|c|c|}
\hline $\mathrm{Nm}$ & $M a$ & $K a$ & $\Sigma$ & $M l$ & $A K B p$ & $4 K B k l$ & $A K B k$ & $\Sigma$ & $\mathrm{Cd}$ & $\mathrm{Vd}$ & $\mathrm{Md}$ & $\mathrm{Kd}$ & $\Sigma$ & $\mu \mathrm{a}$ & $\alpha 1$ & $\mu \mathrm{d}$ & $\sum F u z z y$ \\
\hline $\mathrm{F}$ & 2 & 4 & 6 & 4 & 2 & 3 & 4 & 13 & 5 & 7 & 2 & 6 & 20 & 6 & 13 & 20 & 25,5 \\
\hline G & 4 & 4 & 8 & 1 & 6 & 6 & 4 & 17 & 5 & 7 & 5 & 4 & 21 & 8 & 17 & 21 & 46,4 \\
\hline $\mathrm{H}$ & 6 & 4 & 10 & 8 & 6 & 3 & 2 & 19 & 5 & 7 & 5 & 6 & 23 & 10 & 19 & 23 & 61,3 \\
\hline A & 6 & 7 & 13 & 8 & 6 & 6 & 4 & 24 & 5 & 7 & 2 & 5 & 20 & 13 & 24 & 21 & 76,7 \\
\hline B & 6 & 7 & 13 & 6 & 6 & 6 & 4 & 22 & 5 & 7 & 5 & 6 & 23 & 13 & 22 & 23 & 78,8 \\
\hline $\mathrm{E}$ & 6 & 7 & 13 & 6 & 6 & 6 & 4 & 22 & 5 & 7 & 7 & 6 & 25 & 13 & 22 & 25 & 78,8 \\
\hline $\mathrm{J}$ & 6 & 7 & 13 & 6 & 6 & 6 & 4 & 22 & 5 & 7 & 7 & 6 & 25 & 13 & 22 & 25 & 78,8 \\
\hline K & 6 & 7 & 13 & 6 & 6 & 6 & 4 & 22 & 5 & 7 & 7 & 6 & 25 & 13 & 22 & 25 & 78,8 \\
\hline $\mathrm{L}$ & 6 & 7 & 13 & 6 & 6 & 6 & 4 & 22 & 5 & 7 & 7 & 6 & 25 & 13 & 22 & 25 & 78,8 \\
\hline $\mathrm{M}$ & 6 & 7 & 13 & 6 & 6 & 6 & 4 & 22 & 5 & 7 & 7 & 6 & 25 & 13 & 22 & 25 & 78,8 \\
\hline $\mathrm{N}$ & 6 & 7 & 13 & 6 & 6 & 6 & 4 & 22 & 5 & 7 & 7 & 6 & 25 & 13 & 22 & 25 & 78,8 \\
\hline $\mathrm{O}$ & 6 & 7 & 13 & 6 & 6 & 6 & 4 & 22 & 5 & 7 & 7 & 6 & 25 & 13 & 22 & 25 & 78,8 \\
\hline $\mathrm{P}$ & 6 & 7 & 13 & 6 & 6 & 6 & 4 & 22 & 5 & 7 & 5 & 4 & 21 & 13 & 22 & 21 & 78,9 \\
\hline $\mathrm{Q}$ & 6 & 7 & 13 & 6 & 6 & 6 & 4 & 22 & 5 & 7 & 5 & 2 & 19 & 13 & 22 & 19 & 78,9 \\
\hline $\mathrm{R}$ & 6 & 7 & 13 & 6 & 6 & 6 & 4 & 22 & 5 & 7 & 5 & 2 & 19 & 13 & 22 & 19 & 78,9 \\
\hline $\mathrm{S}$ & 6 & 7 & 13 & 6 & 6 & 6 & 4 & 22 & 5 & 7 & 5 & 4 & 21 & 13 & 22 & 21 & 78,9 \\
\hline $\mathrm{C}$ & 6 & 7 & 13 & 8 & 6 & 6 & 4 & 24 & 5 & 7 & 5 & 6 & 23 & 13 & 24 & 23 & 79,4 \\
\hline D & 6 & 7 & 13 & 8 & 6 & 6 & 4 & 24 & 5 & 7 & 7 & 6 & 25 & 13 & 24 & 25 & 81,7 \\
\hline I & 6 & 7 & 13 & 8 & 6 & 6 & 4 & 24 & 5 & 7 & 7 & 6 & 25 & 13 & 24 & 25 & 81,7 \\
\hline
\end{tabular}

\section{Pengujian Manual}

Proses selanjutnya akan menentukan aplikasi fungsi implikasinya, terdapat 4 aturan fungsi implikasi pada Metode Fuzzy Mamdani, yaitu: Menentukan

[R15] If (Kondisi_Atap is Cukup_Baik) and Fungsi implikasi yang digunakan dalam proses ini (Kondisi_Lantai is Cukup_Baik) and fungsi MIN, yaitu dengan mengambil derajat Kondisi_Dinding is Baik) then (Kelayakan is keanggotaan minimum dari variabel input sebagai RTLH) (1)

[R16] If (Kondisi_Atap is Cukup_Baik) and (Kondisi_Lantai is Cukup_Baik) and (Kondisi_Dinding is Sangat_Baik) then (Kelayakan is RTLH) (1)

[R17] If (Kondisi_Atap is Cukup_Baik) and (Kondisi_Lantai is Baik) and (Kondisi_Dinding is Baik) then (Kelayakan is RLH) (1)

[R18] If (Kondisi_Atap is Cukup_Baik) and (Kondisi_Lantai is Baik) (Kondisi_Dinding is Sangat_Baik) then (Kelayakan is RLH) (1)

\section{Aplikasi Fungsi Implikasi}

Himpunan Fuzzy, Aplikasi Fungsi Implikasi, Komposisi Antar Aturan, Penegasan (deffuzyfication), jika diketahui kondisi atap bernilai 8, lantai 17 dan dinding 21 maka: outputnya. Berdasarkan aturan-aturan yang sesuai dengan fungsi implikasi yaitu ada 18 rule tetapi yang digunakan yaitu dua aturan yaitu [R15], [R16], [R17] dan [R18] sebagai berikut:

$$
\begin{aligned}
\text { xpredikat }_{15} & =\mu_{\text {kaCukup_Baik }} \mu_{\text {klCukup_Baik} \cap} \mu_{\text {kdBaik }} \\
& =\min \left(\mu_{\text {kaCukup_Baik(8), }} \mu_{\text {klCukup_Baik(17), }} \mu_{\text {kdBaik(21) }}\right) \\
& =\min (0.5 ; 0.6 ; 0.75) \\
& =\min (0.5)
\end{aligned}
$$

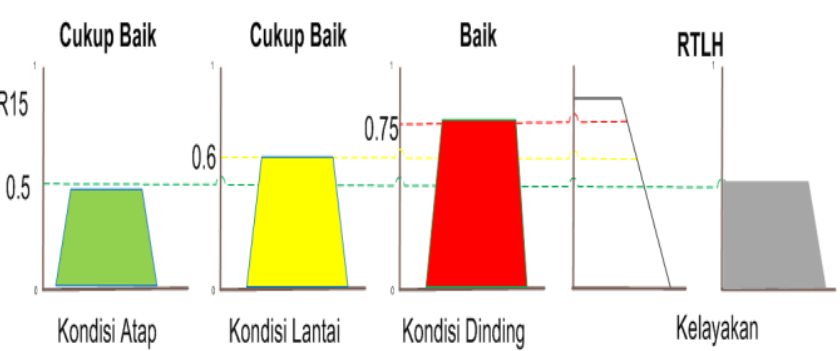

Jurnal RESTI (Rekayasa Sistem dan Teknologi Informasi) Vol. 4 No. 6 (2020) 1179 - 1189 
Gambar 10. Aplikasi Fungsi Implikasi Rule 15

$$
\begin{aligned}
\alpha & =\mu_{\text {kaCukup_Baik }} \mu_{\text {klCukup_Baik } \cap} \mu_{k d S a n g a t B a} \\
- \text { predikat } & \\
& =\min \left(\mu_{\text {kacukup_baik(8), }} \mu_{\text {klCukupBaik(17), }} \mu_{K d}\right. \\
& =\min (0.5 ; 0.6 ; 0.2) \\
& =\min (0.2)
\end{aligned}
$$

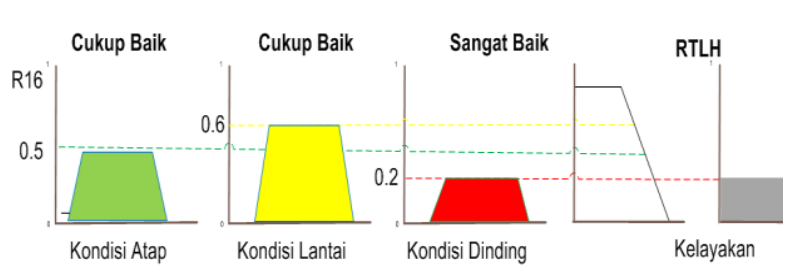

Gambar 11. Aplikasi Fungsi Implikasi Rule 16

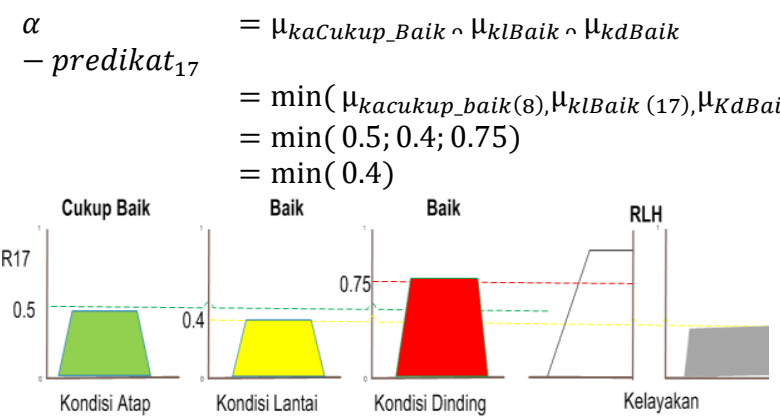

Gambar 12. Aplikasi Fungsi Implikasi Rule 17

$$
\begin{array}{ll}
\alpha & =\mu_{\text {kaCukup_Baik }} \mu_{\text {klBaik }_{n}} \mu_{\text {kdSangatBaik }} \\
- \text { predikat }_{1} & =\min \left(\mu_{\text {kacukup_baik }(8),} \mu_{\text {klBaik(17), }} \mu_{\text {KdSangc }}\right. \\
& =\min (0.5 ; 0.4 ; 0.2) \\
& =\min (0.2)
\end{array}
$$

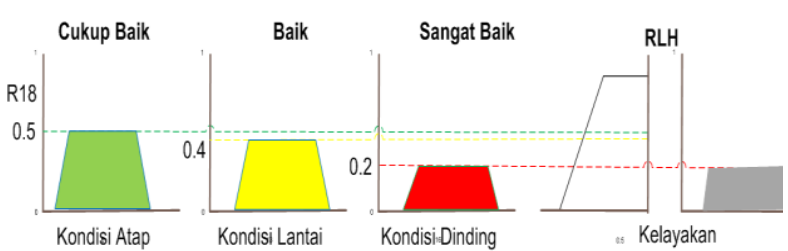

Gambar 12. Aplikasi Fungsi Implikasi Rule 18

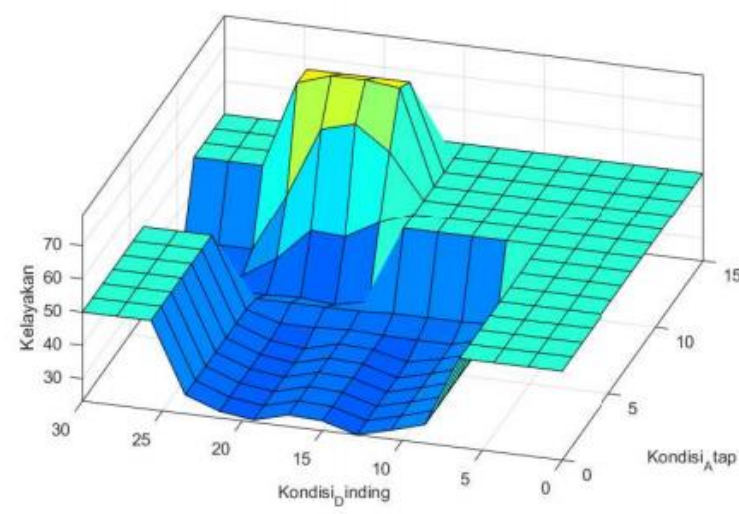

Gambar 13. Surface viewer

\section{Komposisi Aturan}

Tahap ketiga dari prosedur metode fuzzy mamdani adalah komposisi aturan. Pada tahap ketiga ini, suatu prosedur dengan tujuan untuk menentukan inferensi dari kumpulan dan korelasi antar aturan menggunakan Metode Max Min.

Dengan makna lain yaitu prosedur menggabungkan fungsi keanggotaan dari aturan aplikasi fungsi implikasi. Solusi himpunan fuzzy diperoleh dengan cara mengambil nilai maksimum aturan, kemudian menggunakannya untuk memodifikasi daerah fuzzy dan mengaplikasikannya ke dalam output (keputusan akhir) dengan menggunakan operator OR (union). Apabila semua proposisi telah dievaluasi, maka output akan berisi suatu himpunan fuzzy yang merefleksikan kontribusi dari setiap proposisi.

indeari) hasil aplikasi fungsi implikasi dari tiap aturan digunakan metode MAX untuk melakukan komposisi antar semua aturan seperti hasil dibawah ini:

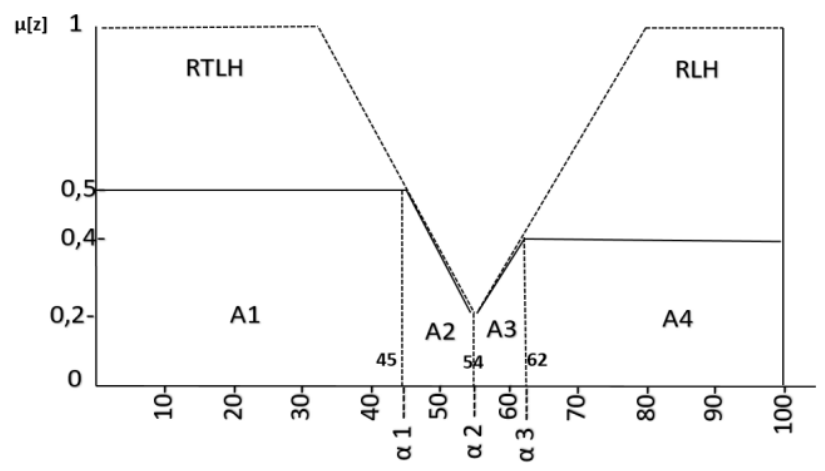

Gambar 14. Daerah Hasil Komposisi

Pada gambar di atas daerah bagi menjadi 3 bagian yaitu A1, A2, A3, dan A4, yang akan dicari nilai $a_{1}, a_{2}, a_{3}$ a1,dan a2 sebagai berikut :

$$
\begin{aligned}
& 0.5 \rightarrow a_{1}=45 \\
& 0.2 \rightarrow a_{2}=54 \\
& 0.4 \rightarrow a_{3}=62
\end{aligned}
$$

\section{Defuzzyfikasi}

Metode penegasan yang akan kita gunakan adalah metode centroid. Untuk itu kita akan menghitung setip momen yang ada :

$\mathrm{M} 1=\int_{0}^{45}(0.5) \mathrm{zdz}=\left.(0.25) \mathrm{z}^{2}\right|_{0} ^{45}=506.25$

$\mathrm{M} 2=\int_{45}^{54}\left(\frac{60-x}{30}\right) \mathrm{zdz}=\frac{1539}{10}=153,9$ 


$$
\begin{aligned}
& \mathrm{M} 3=\int_{54}^{62}\left(\frac{x-50}{30}\right) \mathrm{zdz}=\int_{54}^{62}\left(\frac{1}{30} x-\frac{5}{3}\right) \mathrm{z} \mathrm{dz}=\frac{5632}{45} \\
& =125,16 \\
& \mathrm{M} 4=\int_{62}^{100}(0.4) \mathrm{z} \mathrm{dz}=\left.(0.4) \mathrm{z}^{2}\right|_{62} ^{100}=\left.0.16 \mathrm{z}^{2}\right|_{62} ^{100} \\
& =1600-615=1231.2
\end{aligned}
$$

Kemudian dihitung luas setiap daerah :

$$
\begin{aligned}
\mathrm{A} 1 & =45 * 0.5 \\
& =22.5 \\
\mathrm{~A} 2 & =(54-45) *(0.5+0.2) / 2 \\
& =3.15 \\
\mathrm{~A} 3 & =(62-54) *(0.4+0.2) / 2 \\
& =2.4 \\
\mathrm{~A} 4 & =(100-62) * 0.4 \\
& =15.2
\end{aligned}
$$

Menghitung titik pusat :

$$
\begin{aligned}
& z=\frac{506.25+153,9+125,16+1231.2}{22.5+3.15+2.4+15.2} \\
& z=\frac{2.1016 . .51}{43.25}=\mathbf{4 6 . 6 2 4}
\end{aligned}
$$

Jadi hasil yang didapatkan dari kondisi diatas adalah 46.6 jika dibandingkan dengan hasil yang diperoleh dari software matlab 46.624 maka terjadi 0.024 sebagai toleransi kesalahan saat dilakukan penghitungan manual.

\section{Kesimpulan}

Berdasarkan hasil implementasi aplikasi dan analisis sebanyak 6.998 data rumah di Kecamatan Tanjung Harapan Kota Solok Provinsi Sumatera Barat, ada sebanyak 300 unit rumah tidak layak huni. Maka dapat disimpulkan penerapan dan pengujian menggunakan algoritma fuzzy logic metode mamdani membantu dalam pembentukan pola penentuan kelayakan semesta pembicaraan himpunan fuzzy $0-100$ atau 0 sd 100 persen, sehingga keputusan linguistik yang didapatkan tidak hanya layak atau tidak layak akan tetapi mampu mengurutkan dalam prioritas hunian mana yang perlu diperhatikan, nilai yang diperoleh akan mengalami perbedaan tergantung kondisinya, berdasarkan hasil penghitungan tersebut diharapkan pemerintah dan stakeholder terbantu dan mendukung keputusan bukan menggantikan keputusan dalam menyusun program kebijakan, perencanaan, dan penganggaran pembangunan yang optimal sesuai dengan fakta dan data lokasi di lapangan sebagai penunjang keputusan.

\section{Ucapan Terimakasih}

Terima kasih kepada Ristekdikti dalam pendanaan penelitian dosen pemula tahun pelaksanaan 2020 dan kepada Pemerintah Kota Solok Provinsi Sumatera Barat dan semua pihak terkait yang telah membantu dari sisi perizinan penyediaan data dalam penelitian ini. Semoga penelitian ini dapat bermanfaat untuk semua pihak yang membutuhkan.

\section{Daftar Rujukan}

[1] Presiden Republik Indonesia, "Peraturan Pemerintah Republik Indonesia Nomor 38 Tahun 2007 Tentang Pembagian Urusan pemerintahan Antara Pemerintah, Pemerintah daerah Provinsi, dan Pemerintahan Daerah Kabupaten/Kota," Menkumham RI, 2007.

[2] R. N. P. Rakyat, "peraturan menteri negara perumahan rakyat republik indonesia nomor: 22/permen/m/2008," no.112, 200, vol. 22, no. 7, pp. 874-882, 2008, doi: 10.1093/bioinformatics/btk045.

[3] J. Subianto, "Peran Keluarga, Sekolah, Dan Masyarakat Dalam Pembentukan Karakter Berkualitas," Edukasia J. Penelit. Pendidik. Islam, vol. 8, no. 2, pp. 331-354, 2013, doi: 10.21043/edukasia.v8i2.757.

[4] M. A. Sitorus, "Integrasi Pendidikan Kependudukan Kedalam Kurikulum dalam Rangka Pencapaian Target Sustainable Development Goals (Sdgs) Di Indonesia," Pros. Semin. Nas. Tah. Fak. Ilmu Sos. Univ. Negeri Medan Tahun, 2017.

[5] J. Kementerian Sosial, "Peraturan Menteri Sosial Republik Indonesia Nomor 20 Tahun 2017 Tentang Rehabilitasi Sosial Rumah Tidak Layak Huni Dan Sarana Prasarana Lingkungan," BMC Public Health, vol. 5, no. 1, pp. 1-8, 2017, [Online]. Available:

https://jdih.kemsos.go.id/pencarian/www/index.php/web/resul t/4901/detail.

[6] B. Sunaryo, M. I. Rusydi, A. Manab, A. Luthfi, . R., and T. Septiana, "Sistem Informasi Manajamen Perangkat Elektronik Berbasis Web," J. Nas. Teknol. Dan Sist. Inf., 2016, doi: 10.25077/teknosi.v2i1.2016.75-82.

[7] Kemen PUPR RI, "Permen PUPR No. 8," https://www.pu.go.id/assets/announcements/Permen-PUPRNo-8-Tahun-2020.pdf, vol. 2020, 2020, [Online]. Available: https://www.pu.go.id/assets/announcements/Permen-PUPR-

No-8-Tahun-2020.pdf.

[8] Pemerintah Republik Indonesia, "Undang-Undang Republik Indonesia Nomor 23 tahun 2014 tentang Pemerintahan Daerah," Kementeri. Sekr. Negara RI, 2014, doi: 10.1017/CBO9781107415324.004.

[9] M. P. U. D. P. R. R. Indonesia, "peraturan menteri pekerjaan umum dan perumahan rakyat republik indonesia nomor 47/prt/m/2015 tentang petunjuk teknis penggunaan dana alokasi khusus bidang infrastruktur," menteri pekerj. Umum dan perumah. Rakyat republik indones., vol. 27, no. 9, pp. 3505-3515, 2019

[10] E. S. Dewi Teresia and H. Hermi, "pengaruh struktur kepemilikan, ukuran perusahaan dan keputusan keuangan terhadap nilai perusahaan dengan pertumbuhan perusahaan sebagai variabel moderating," J. Magister Akunt. Trisakti, 2016, doi: 10.25105/jmat.v3i1.4969.

[11] K. Jayakumar, "Managing mangrove forests using open source-based webgis," in Coastal Management: Global Challenges and Innovations, 2018.

[12] D. L. Rahakbauw, F. J. Rianekuay, and Y. A. Lesnussa, "Penerapan Metode Fuzzy Mamdani Untuk Memprediksi Jumlah Produksi Karet (Studi Kasus: Data Persediaan Dan Permintaan Produksi Karet Pada Ptp Nusantara Xiv (Persero) Kebun Awaya, Teluk Elpaputih, Maluku-Indonesia)," J. Ilm. Mat. Dan Terap., vol. 16, no. 1, pp. 51-59, 2019, doi: 10.22487/2540766x.2019.v16.i1.12764.

[13] K. Soundararajan, S. Sureshkumar, and C. Anusuya, "Diagnostics Decision Support System for Tuberculosis using Fuzzy Logic," IRACST - Int. J. Comput. Sci. Inf. Technol. Secur., vol. 2, no. 3, pp. 684-689, 2012.

[14] J. Alam, "Design and Analysis of a Two Stage Traffic Light 
System Using Fuzzy Logic," J. Inf. Technol. Softw. Eng., vol. 05, no. 03, 2015, doi: 10.4172/2165-7866.1000162.

[15] M. Tan and J. Xu, "Journal of Information Technology Management A Publication of the Association of Management study and implementation of a decision support system for urban mass transit service planning abstract," J. Inf. Technol., vol. XV, pp. 14-32, 2004.

[16] S. Li, B. Davies, J. S. Edwards, R. Kinman, and Y. Duan, "Integrating group Delphi, fuzzy logic and expert systems for marketing strategy development: the hybridisation and its effectiveness," no. 2000, pp. 1-19, 2002, doi: $10.1108 / 02634500210441521$.

[17 ] K. Hamdi, B. Sunaryo, A. Arianto, Yuhefizar, and I. Gunawan, "Sistem Pelacakan Lokasi Petugas Survei RTLH Menggunakan GPS Android dan WebGIS", RESTI, vol. 3, no. 3, pp. 552 - 559, Dec. 2019.

[18] O. J.C and I. A.a, "Decision Support System for the Intelligient Identification of Alzheimer using Neuro Fuzzy logic," Int. J. Soft Comput., vol. 2, no. 2, pp. 25-38, 2011, doi: 10.5121/ijsc.2011.2203. 